\title{
Breast feeding and the risks of viral transmission
}

Specialised epidermal secretions developed as nutritious and bacteriostatic factors some 120 million years ago; milk production has proved a crucial factor to mammalian survival in a wide range of habitats. Milk composition differs considerably between phyla, within species, and with time in an individual lactating mother. The neonatal period claims the greatest infectious toll in mammals so that from an evolutionary standpoint there must be a balance in favour of producing and consuming milk without increasing susceptibility to infection. Competitive interaction with viruses, bacteria, and protozoans has resulted in the development of unique characteristics within breast epithelial cells. Unlike equivalent cells in sweat or salivary glands, they secrete nutritive molecules, antibiotic substances, growth factors, inflammatory cytokines, and chemokines while regulating a physiological recruitment of lymphoid and myeloid cells from the circulation into the milk. Milk therefore has functions other than nutrition; milk is a complex mixture of cells, membranes, and molecules. Epidemiological data from the HIV pandemic have highlighted our lack of knowledge about this secretion.

It was established in the 1960 s that milk was a significant source of infection to mouse pups for Moloney leukaemia virus, sarcoma virus, and mammary tumour virus: other species show similar patterns of transmission of lentiviruses. ${ }^{1}$ In man the RNA retroviruses including HIV-1, HTLV-1, and HTLV-2 are all transmitted by this route. ${ }^{2}$ It has been recorded that HIV-2 is not transmitted by breast milk, but it is probable that there is a relatively lower risk in this less virulent retrovirus as well as fewer data to assess infectivity. Cytomegalovirus is possibly the most commonly detectable virus in milk: it is thought that reactivation of virally infected breast epithelial cells in early lactation promotes the shedding of infectious free virus particles. ${ }^{3}$ Rubella, herpes simplex, and rarely hepatitis $\mathrm{B}$ can be passed on to the infant too if mothers have an active infection. ${ }^{4}$ EBV and HHV6 may be found in human milk, but large serological studies suggest that they rarely infect the breast fed neonate. ${ }^{5}$ Hepatitis C RNA has not been detected in milk in one series, and the infection rate by this route is probably low unless the maternal viral load is high..$^{6-8}$

The challenge to clinicians is therefore to determine the risk to any particular infant of milk borne infection: can one estimate the hit rate of these organisms in milk? Reports from various populations show a range of infectious rates for cytomegalovirus $(40-76 \%),{ }^{9}{ }^{10}$ rubella $(25-50 \%),{ }^{4}$ HTLV-1 (80\%), ${ }^{11}$ and HIV-1 (5-66\%). ${ }^{12-14}$ A meta-analysis approach estimated an additional risk of $14 \%$ (95\% confidence interval $7-22 \%$ ) of mother to child HIV infection conferred by breast feeding ${ }^{13}$; an increased risk of $26 \%$ (95\% CI $13-39 \%$ ) for incident cases. ${ }^{14}$ These wide ranges of hit rates indicate a complexity in the underlying process of transmission which merit clarification. Given the volume of milk consumed daily by an infant it is surprising that milk is not more infectious, and there are clearly strong protective factors at work. At present there are insufficient data to rank known risk factors most likely to increase maternal infectivity or infant susceptibility (table 1), let alone disease severity. Milk constituents vary considerably between mothers, and over time in a single woman, rendering many objective measures impractical. Milk composition is influenced by gestation, treatment with steroids, or psychological stress: the interactions between these events and the roles of breast epidermal cells remain unclear.
Epidemiological work with HTLV-1 and HIV has provided a range of data on the risk of acquiring infection at different stages of lactation. ${ }^{11-16}$ Claims have been made for lower infection rates early in lactation, for instance, but many of these studies did not determine whether mothers breast fed exclusively, a factor which may be critical to viral transmission. A recent study in a South African population suggested that mixed formula and breast feeding was more likely to promote HIV-1 transmission than exclusive breast feeding, and for this reason studies of exclusive breast feeding are being carried in Durban. ${ }^{13}$ This work is critical to infants in the developing world, for whom exclusive breast feeding may often be the safest option, particularly if clean water is not available. These problems revolve around our lack of precise knowledge as to the mechanisms whereby virus infects the breast feeding infant. Retroviruses may infect the mammary epithelial cell antenatally; they are also found free in solution and within milk monocytes which comprise about $50 \%$ of the cells in healthy milk. ${ }^{17}$ (These cells normally protect the glandular tissues as phagocytes and by providing professional local antigen presentation; they may have similar functions in the neonatal gut. ${ }^{19}{ }^{19}$ ) Maternal cells may therefore have the potential to carry viruses from mother's circulation or lymphoid tissues into the neonatal gut. Studies of HIV strains add further complexity: most adult HIV infections develop from macrophage-tropic strains of the virus which utilise the chemokine receptor CCR5. However CCR5 chemokine receptor heterozygosity does not protect infants against infection by breast feeding (although the mutation $\Delta 32$ in the CCR5 receptor may protect against infection in utero).$^{20}$ Perhaps orally delivered virus enters the infant via cells which do not bear these receptors: such portals could include enterocytes and $M$ cells in the infant gut, which in animal models take up free virus from the intestinal lumen. The precise role of milk cells in viral infection and the range of viral portals of entry have therefore to be elucidated. ${ }^{21}$

Clinical mastitis and breast abscesses increase the rate of vertical viral transmission: this aspect of maternal health tends to reflect the adequacy of support and information provided to breast feeding mothers, as these disorders are often preventable. ${ }^{22}$ Subclinical mastitis merits careful consideration: this term describes bacteriologically culture positive milk without clinical symptoms: there is an associated increase in milk sodium concentration, cell counts, inflammatory cytokines, enzymes, and reduced milk production. ${ }^{23}$ Samples from several communities suggest rates of $20-33 \%$ of this entity which may promote infection of the infant with HIV (there are no data relating to other viruses).$^{24}$ Mastitis causes immune activation in the breast promoting viral transmission by the production of

Table 1 Factors promoting or inhibiting transmission of virus by breast feeding

\begin{tabular}{|c|c|}
\hline Promoting & Inhibitory \\
\hline Milk viral load/infected milk cell count & Antiviral antibody ${ }^{32}$ \\
\hline Clinical mastitis, abscess ${ }^{2027}$ & TGF- $\beta^{33}$ \\
\hline Subclinical mastitis ${ }^{38}$ & High carotenoid levels ${ }^{34}$ \\
\hline Multiple maternal viral infections & Lactoferrin $^{35}$ \\
\hline Mixed feeding ${ }^{11}$ & Protease inhibitor SLP1 ${ }^{36}$ \\
\hline Prematurity, mouth ulcers in infant & Lipid molecules $^{37}$ \\
\hline RANTES, GM-CSF ${ }^{28}$ & $\begin{array}{l}\text { Specific T lymphocyte killing } \\
\text { Lysozyme, mucins }\end{array}$ \\
\hline Inclear: & $\begin{array}{l}\text { Antiviral drugs } \\
\text { dants, lipids, trace elements, vitamins), } \\
\text { story }\end{array}$ \\
\hline
\end{tabular}


activated cells (dendritic cells in particular) and mediators known to induce viral replication in breast epithelium and activate infant enterocytes. The same may be true of subclinical mastitis. The comparative significance of these observations has to be determined, but active management of clinical mastitis offers mothers, midwives, and doctors an opportunity to reduce the risks of vertical viral transmission. Enhancing maternal nutrition (perhaps with trace elements, vitamins, and antioxidants) or enhancing genetic resistance to reduce subclinical or clinical mastitis through diet or medications will diminish the risks of milk borne viral transmission. ${ }^{25}$

Can breast milk be cleared of viruses? In the case of retroviruses, might milk be washed as may semen in order to remove active virus? Although one might conceivably remove cell associated virus by filtering, free viral particles are difficult to eliminate. Pasteurisation to $62.5^{\circ} \mathrm{C}$ will destroy infectious viral particles, but this also alters milk composition to a significant degree, and in practical terms is often limited by the requirement for scrupulous hygiene. ${ }^{26} 27$ Protective mechanisms of the innate and cellular immune system at work during lactation could potentially be exploited by vaccination. Such approaches need to be extensively tested in an appropriate animal model: in dairy cows protection against bacterial infection has been enhanced using this approach. Most promising of all for short term approaches to retroviruses are therapeutic studies showing that a single dose of nevirapine, a nonnucleoside reverse transcriptase inhibitor, can clear milk of virus and so permit safe early breast feeding. ${ }^{28}$ Provision of cut price or free nevirapine by non-governmental organisations and pharmaceutical companies to many African countries has made this a readily available treatment. However, widespread use of a single agent in this setting will encourage the development of resistance and may be associated with rebound viraemia when the agent is stopped, with a potential increase in maternal infectivity and as yet undetermined effects on maternal health. ${ }^{21}$

Paediatricians will have to dedicate greater effort to estimating the risks posed by vertical viral transmission by breast feeding. Milk banks with pasteurised milk and wet nursing practices may offer local solutions, but will require vigilant supervision. Perhaps the monitoring of milk cell counts or sodium concentrations in addition to bacteriological screening should be studied as a potential method of quality control for such sources. At a global level, there must be a continued commitment to supporting breast feeding as the safest form of infant nutrition for those mothers who do not have an active viral infection: the situation is rarely one of tainted breast milk, but t'aint enough.

We should like to thank Dr Donald Bentley, Professor Angus Nicoll, and Professor Felicity Savage for their helpful comments during the preparation of this review.

C A MICHIE

Department of Paediatrics, Ealing Hospital NHS Trust, Middlesex, UK

J GILMOUR

Department of Immunology, Chelsea and Westminster Hospital, London, UK

Correspondence to: Dr Michie

colinm@easynet.co.uk

\section{Appendix-useful websites}

Biology of the Mammary Gland website: http://biomednet.com/hmsbeagle/33/webres/ wreview.htm

International Society for Lactation: http://www.ISRHML.org

Academy of Breastfeeding Medicine:

BFMEO.org; Jdawson@goAMP.com
Training websites:

www.breastfeedingbasics.org

www.CN.edu/med/breastfeeding

1 Ruprecht RM, Baba TW, Liska V, et al. Oral transmission of primate lentiviruses. Infect Dis 1999;179:S408-12.

2 LeVasseur RJ, Southern SO, Southern PJ. Mammary epithelial cells support and transfer productive human T-cell lymphotropic virus infections. F Hum Virol 1998;1:214-23

3 Minamishima I, Ueda K, Minematsu T, et al. Role of breast milk in acquisition of cytomegalovirus infection. Microbiol Immunol 1994;38:549-52.

4 Losonsky GA, Fishaut JM, Strussenberg J, et al. Effect of immunization against rubella on lactation products. II. Maternal-neonatal interactions. $\mathcal{F}$ Infect Dis 1982;145: 661-6.

5 Kusuhara K, Takabayashi A, Ueda K, et al. Breast milk is not a significant source for early Epstein-Barr virus or human herpesvirus 6 infection in infants: a seroepidemiologic study in 2 endemic areas of human T-cell lymphotropic virus type I in Japan. Microbiol Immunol 1997;41:309-12.

6 Croxson M, Couper A, Voss L, et al. Vertical transmission of hepatitis C virus in New Zealand. $N Z$ Med $\mathcal{F} 1997 ; 110: 165-7$.

7 Polywka S, Feucht H, Zollner B, et al. Hepatitis C virus infection in pregnancy and the risk of mother-to-child transmission. Eur f Clin Microbiol Infect Dis 1997;16:121-4.

8 Kumar RM, Shahul S. Role of breast feeding in transmission of hepatitis C virus to infants of HCV-infected mothers. F Hepatol 1998;29:191-7.

9 Dirus to infants of HCV-infected mothers. F Hepatol 1998;29:191-7. milk and transmission in infancy. Pediatrics 1983;72:295-9.

10 Vochem M, Hamprecht MD, Jahn G, et al. Transmission of cytomegalovirus to preterm infants through breastmilk. Pediatr Infect Dis 1998;17:53-8.

11 Hino S, Katamine S, Kawase K, et al. Intervention of maternal transmission of HTLV-1 in Nagasaki, Japan. Leukemia 1994;8:S68-70.

12 Miotti PG, Taha TE, Kumwenda NI, et al. HIV transmission through breastfeeding: a study in Malawi. $7 A M A$. 1999;282:744-9.

13 Coutsoudis A, Pillay K, Spooner E, et al. Influence of infant-feeding patterns on early mother-to-child transmission of HIV-1 in Durban, South Africa: a prospective cohort study. Lancet 1999;354:471-6.

14 Ekpini ER, Wiktor SZ, Satten GA, et al. Late postnatal mother-to-child transmission of HIV-1 in Abidjan, Cote d'Ivoire. Lancet 1997;349:1054-9.

15 Dunn DT, Newell ML, Ades AE, et al. Risk of human immunodeficiency virus type 1 transmission through breastfeeding. Lancet 1992;340:5858.

16 Van de Perre P. Postnatal transmission of the human immunodeficiency virus type 1 and the breastfeeding dilemma. Am f Obstet Gynecol 1995;173: 4837

17 Lewis P, Nduati R, Kreiss JK. Cell-free human immunodeficiency virus type 1 in breast milk. F Infect Dis 1998;177:34-9.

18 Michie CA, Tantschler E, Rot A. The long term effects of breast feeding-a role for the cells in breast milk? F Trop Pediatr 1998;44:1-3.

19 Fitzpatrick JL, Williams NA, Bailey M, et al. Presentation of soluble and bacterial antigens by milk-derived cells to unprimed bovine $\mathrm{T}$ cells in vitro. Vet Immunol Immunopathol 1995;46:251-66.

20 Philpott S, Burger H, Charbonneau T, et al. CCR5 genotype and resistance to vertical transmission of HIV-1. I Acquir Immune Defic Syndr 1999;21:189-9.

21 Van de Perre P. Transmission of human immunodeficiency virus type through breast-feeding: how can it be prevented? F Infect Dis 1999;179: S405-7.

22 WHO, Department of Child and Adolescent Health and Development. Mastitis: causes and management. WHO/FCH/CAH/00.13. Geneva: WHO, 2000

23 Semba RD, Kumwenda N, Taha TE, et al. Mastitis and immunological factors in breast milk of human immunodeficiency virus-infected women. 7 Hum Lact 1999;15:301-6.

24 Semba RD, Kumwenda N, Hoover DR, et al. Human immunodeficiency virus load in breast milk, mastitis, and mother-to-child transmission of human immunodeficiency virus type 1. F Infect Dis 1999;180:93-8.

25 Tomkins A. Malnutrition, morbidity and mortality in children and their mothers. Proc Nutr Soc 2000;59:135-46.

26 Lawrence RA. Storage of human milk and the influence of procedures on immunological components of human milk. Acta Paediatr Suppl 1999;88: 14-18.

27 Wright KC, Feeney AM. The bacteriological screening of donated human milk: laboratory experience of British Paediatric Association's published guidelines. F Infect 1998;36:23-7.

28 Musoke P, Guay LA, Bagenda D, et al. A phase I/II study of the safety and pharmacokinetics of nevirapine in HIV-1 infected pregnant Ugandan women and their neonates (HIVNET 006). AIDS 1999;13:479-86.

29 Prentice A, Prentice AM, Lamb WH. Mastitis in rural Gambian mothers and the protection of the breast by milk antimicrobial factors. Trans $R$ Soc Trop Med Hyg 1985;79:90-5.

30 Michie C, Tantschler E, Schall T, et al. Physiological secretion of chemokines in human breast milk. Eur Cytokine Network 1998;9:123-9.

31 Sozzani S, Allavena P, Vecchi A, et al. The role of chemokines in the regula tion of dendritic cell trafficking. F Leukoc Biol 1999;66:1-9.

32 Saha K, Hollowell D, Wong PK. Mother-to-baby transfer of humoral immunity against retrovirus-induced neurologic disorders and immunodeficiency. Virology 1994;198:129-37.

33 Geissman F, Revy P, Regnault A, et al. TGF- $\beta 1$ prevents the noncognate maturation of human dendritic Langerhans cells. F Immunol 1999;162: 4567-75.

34 Filteau AM, Lietz G, Mulokozi G, et al. Milk cytokines and subclinical breast inflammation in Tanzanian women: effects of dietary red palm oil or sunflower oil supplementation. Immunology 1999;97:595-600.

35 Swart PJ, Kuipers EM, Smit C, et al. Antiviral activity of lactoferrin. Adv Exp Med Biol 1998;443:205-13.

36 Janoff EN, Eidman K, McNeely TB, et al. Secretory leukocyte protease inhibitor (SLPI), an HIV-1 inhibitory protein and rates of HIV-1 transmission by mucosal fluids. In: Proceedings of the Conference on HIV-1 and sion by mucosal fuids. In: Proceedings of the Conferent Pathogenesis, NIH, Bethesda MD, 1997:1113.

37 Isaacs CE, Kim KS, Thormar H. Inactivation of enveloped viruses in human bodily fluids by purified lipids. Ann N Y Acad Sci 1994;724:457-64.

38 Urech E, Puhan Z, Schallibaum $M$. Changes in milk protein fraction as affected by subclinical mastitis. F Dairy Sci 1999;82:2402-11. 